\title{
Tautocrowns: a concept for a sensing molecule with an active side-arm
}

\author{
Liudmil M. Antonov a,*, Vanya B. Kurteva ${ }^{\mathrm{a}, *}$, Svilen P. Simeonov ${ }^{\mathrm{a}}$, Vera V. Deneva ${ }^{\mathrm{a}}$, \\ Aurelien Crochet ${ }^{\mathrm{b}}$, Katharina M. Fromm ${ }^{\mathrm{b}}$ \\ a Institute of Organic Chemistry with Centre of Phytochemistry, Bulgarian Academy of Sciences, Acad. G. Bonchev str., bl. 9, 1113 Sofia, Bulgaria \\ ${ }^{\mathrm{b}}$ University of Fribourg, Department of Chemistry, Chemin du Musée 9, CH-1700 Fribourg, Switzerland
}

\begin{abstract}
A new sensing molecule containing aza-15-crown-5 as a receptor and 4-(phenyldiazenyl)naphthalen-1ol as a signal converter has been synthesized. In the free ligand, the hydrogen bonding between the tautomeric $\mathrm{OH}$ group and the nitrogen atom from the macrocycle fully shifts the tautomeric equilibrium towards the enol form. The complexation reverses the equilibrium as a result of the strong interaction between the metal ion captured in the macrocyclic moiety and the tautomeric carbonyl group. The complex formation is accompanied by strong bathochromic (between 60 and $100 \mathrm{~nm}$ ) and hyperchromic effects on the absorption spectra. Obviously, the tautomeric $\mathrm{OH} / \mathrm{C}=\mathrm{O}$ groups play the role of an active side-arm in the complexation, supporting it via formation of a 3D cavity and giving possibility for ejection of the guest compound under stimuli to shift the tautomeric process back.
\end{abstract}

\section{Introduction}

Intelligent molecules, the structures and properties of which are facilely and reversibly changeable by the application of external physical and chemical stimuli, have attracted much recent attention relative to the development of new molecule-based devices. ${ }^{1}$ Design of artificial receptors for monitoring biologically and environmentally important ionic species in solutions, especially heavy and transition metal cations, is currently of great importance. ${ }^{2-12}$

The most common types of chemosensors consist of two components: a signaling unit and a receptor linked directly or via a spacer. ${ }^{13-16}$ Among the broad variety of species with complexing ability, crown and aza-crown ethers have been approved as efficient selective receptors in chemosensors. ${ }^{17-29}$ In general, their complexing ability and selectivity for metal ions can be varied by changing certain parameters such as the availability and acidity of the passive phenolic $\mathrm{OH}$ side-arm; the size of the crown ether ring;

\footnotetext{
* Corresponding authors. Tel.: +359 29606102 (L.M.A.), +359 29606156 (V.B.K.); fax: +359 2 8700225; e-mail addresses: lantonov@orgchm.bas.bg (L.M. Antonov), vkurteva@orgchm.bas.bg (V.B. Kurteva).
}

type, number and position of the complexing crown ether heteroatoms; the stereochemistry imposed by the arms, which connect the phenolic group to the macrocycle; and the $\mathrm{pH}$ of media. ${ }^{30,31} \mathrm{At}$ the same time, the azo compounds are among the most widely examined colouring and signaling systems due to their optical stability. $^{32-39}$

The new concept of our study is to build a tautomeric switch, where a directed shift in the position of the tautomeric equilibrium can be governed by hydrogen bonding between the tautomeric $\mathrm{OH}$ group and the nitrogen atom in aza-crown ether in the free ligand and by the interaction between the tautomeric carbonyl oxygen and the complexated metal ion. Switching from one to the other tautomeric form under complexation gives sharp and fast changes in the optical properties. The tautomeric $\mathrm{OH}$ and $\mathrm{C}=\mathrm{O}$ groups play the role of an active side-arm in the complexation, supporting it via formation of a 3D cavity and giving possibility for ejection of the guest compound under stimuli to shift the tautomeric process back. The practical applicability of this promising idea was recently proven by us on a model compound possessing a piperidine receptor unit. ${ }^{40}$

In this paper, we report on the synthesis and spectral properties of a compound with an aza-15-crown-5 fragment tethered to 4-(phenyldiazenyl)naphthalen-1-ol. To our best knowledge, this is 
the first example of an active side-arm containing chemosensor with significant bathochromic and hyperchromic effects on the absorption maximum upon protonation or complexation.

\section{Results and discussion}

The target tautocrown $\mathbf{3}$ was obtained from naphthalen-1-ol $\mathbf{1}$ by applying diazo coupling/Mannich reaction sequence (Scheme 1 ), which was established as the only reasonable way to convert $\mathbf{1}$ into 3. The first step was carried out by following a standard procedure and the product $\mathbf{2}$ was further used without chromatography purification. The incorporation of the aza-crown fragment was achieved by $p$-toluenesulfonic acid catalyzed Mannich reaction in good overall yield. When performing the synthesis via the reversed sequence, the intermediate naphthalene-1-ol possessing an azacrown side-chain decomposed during the diazo coupling resulting in a very complicated mixture.

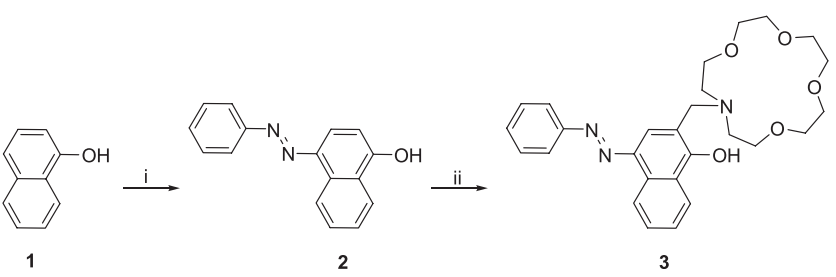

Scheme 1. Synthesis of tautocrown 3: (i) $\mathrm{PhNH}_{2}$, concd $\mathrm{HCl}, \mathrm{NaNO}_{2}$, acetone $/ \mathrm{H}_{2} \mathrm{O}$; (ii) $(\mathrm{HCHO})_{n}, p$-toluenesulphonic acid, 1-aza-15-crown-5, benzene, $47 \%$ overall yield.

Quite surprisingly, when aq $\mathrm{K}_{2} \mathrm{CO}_{3}$ solution was used during the work-up instead of deionized water, the product was isolated as a red crystalline compound possessing unusually high melting point $\left(230-231^{\circ} \mathrm{C}\right)$ and absorption maximum at $518 \mathrm{~nm}$. The latter was identified as a sodium complex $(2: 2)$ of the keto form $(\mathbf{3 K}-\mathbf{N a})$ by NMR and X-ray analyses (Fig. 1). ${ }^{41}$ This fact shows that the ligand binds sodium strongly enough to trap the negligible amount of sodium impurity in potassium carbonate.

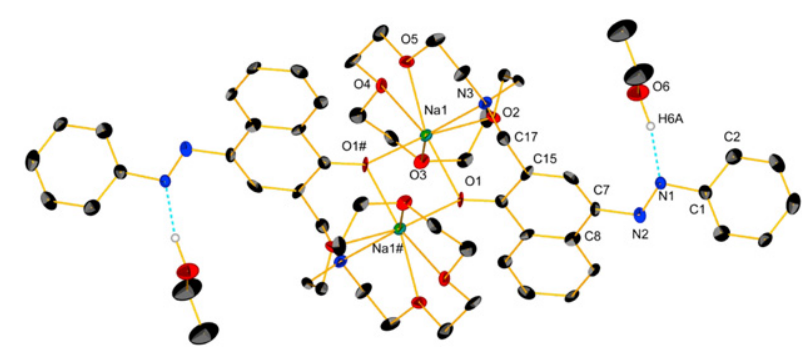

Figure 1. View of molecular structure of $\mathbf{3 K}-\mathbf{N a}$, ellipsoids are $50 \%$, some $\mathrm{H}$ atoms are omitted for clarity. (\#: $-2-x,-y,-1-z)$, $\mathrm{Na}$ atoms are in green, $\mathrm{N}$ in blue, $\mathrm{O}$ in red and $\mathrm{C}$ in black.

The complex $\mathbf{3 K}-\mathbf{N a}$ was converted into $\mathbf{3}$ by treating a $\mathrm{CH}_{3} \mathrm{CN}$ solution with aq ammonia followed by extraction with cyclohexane (Scheme 2).

The tautomeric signal converter, 4-(phenyldiazenyl)naphthalen-1-ol (2), is well known since the 19th century as one of the first tautomeric compounds discovered. ${ }^{42}$ As a result of the moderate energy gap between the enol $(\mathbf{E})$ and the keto $(\mathbf{K})$ tautomeric forms, the tautomeric equilibrium (Scheme 2 ) can be easily shifted in one or another direction by changing the solvent or/and the temperature. However, this equilibrium has never been shifted fully to one of the tautomers. This energy gap, as predicted by the quantum-chemical calculations, is appr. $1.5 \mathrm{kcal} / \mathrm{mol}$, which

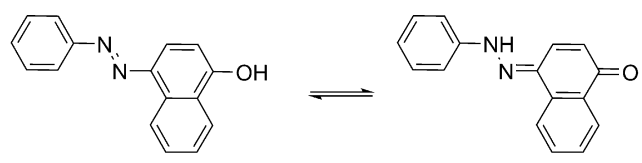

2E

2K

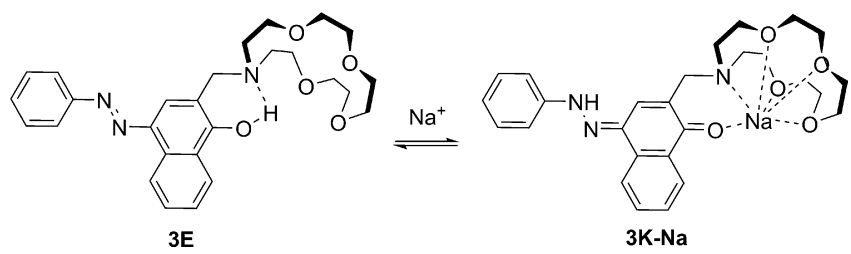

Scheme 2. Tautomeric interconversion in $\mathbf{2}$ and between $\mathbf{3}$ and $\mathbf{3 K}-\mathbf{N a}$.

corresponds to appr. $8 \%$ (in cyclohexane) or $10 \%$ (in methylcycloxehane/toluene) of the keto tautomer (Fig. 2). ${ }^{24,43}$

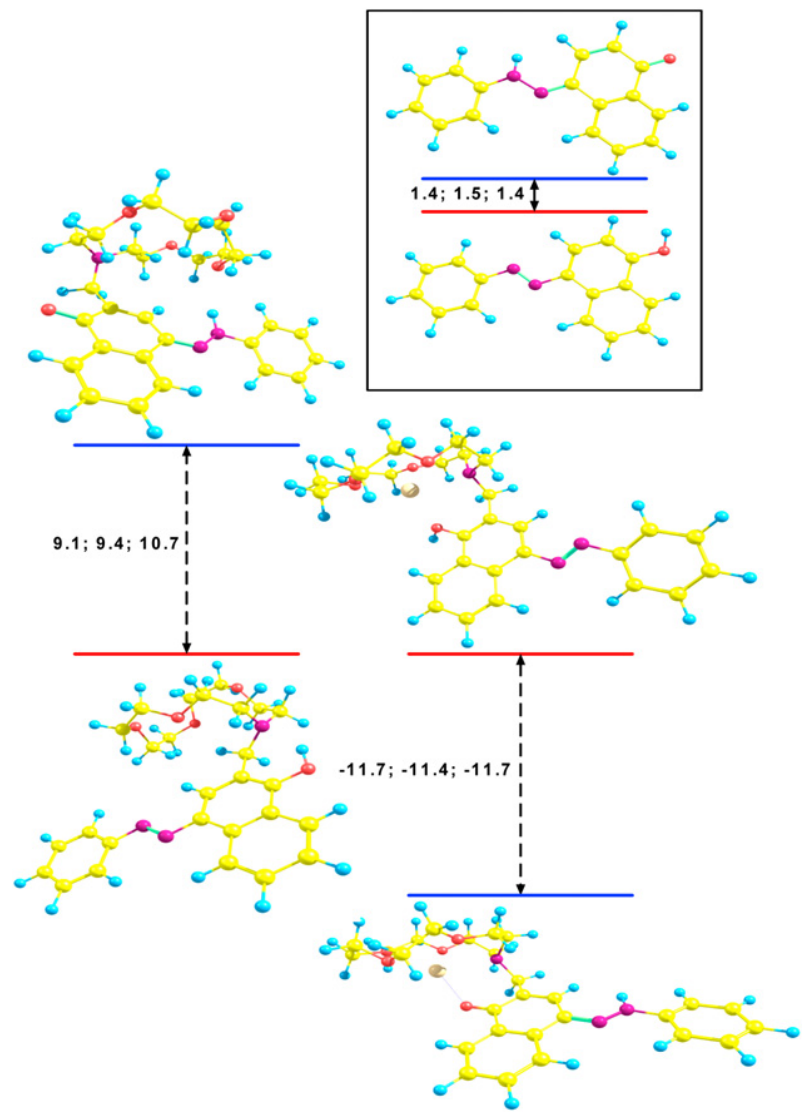

Figure 2. Relative stability $\left(\mathrm{HF} / 6-31 \mathrm{G}^{* *}\right)$ of the tautomers of $\mathbf{2}$ (inset) and $\mathbf{3}$ (as free ligand, left, and as calcium complex, right). The values of the relative energy, relative energy $+Z P E$ correction and $\Delta \Delta G$ are given in $\mathrm{kcal} / \mathrm{mol}$ units.

According to the calculations, shown in Figure 2, the implementation of an aza-15-crown-5 moiety could lead to stabilization of the enol form through hydrogen bonding between the $\mathrm{OH}$ group and the macrocyclic nitrogen. The complexation could fully reverse the equilibrium towards the keto form.

A comparison between the absorption spectra of $\mathbf{2}$ and $\mathbf{3}$ shows that the tautomeric equilibrium in $\mathbf{3}$ is fully shifted towards the enol form, displaying only a band at appr. $410 \mathrm{~nm}$ (Fig. 3). In contrast, in the case of $\mathbf{2}$, the equilibrium is strongly solvent dependent and bands belonging to both tautomers (at $410 \mathrm{~nm}$ for the enol form and at $480 \mathrm{~nm}$ for the keto tautomer, the latter is strongly solvent dependent) are always observed independing on the solvent. ${ }^{39,43}$ 


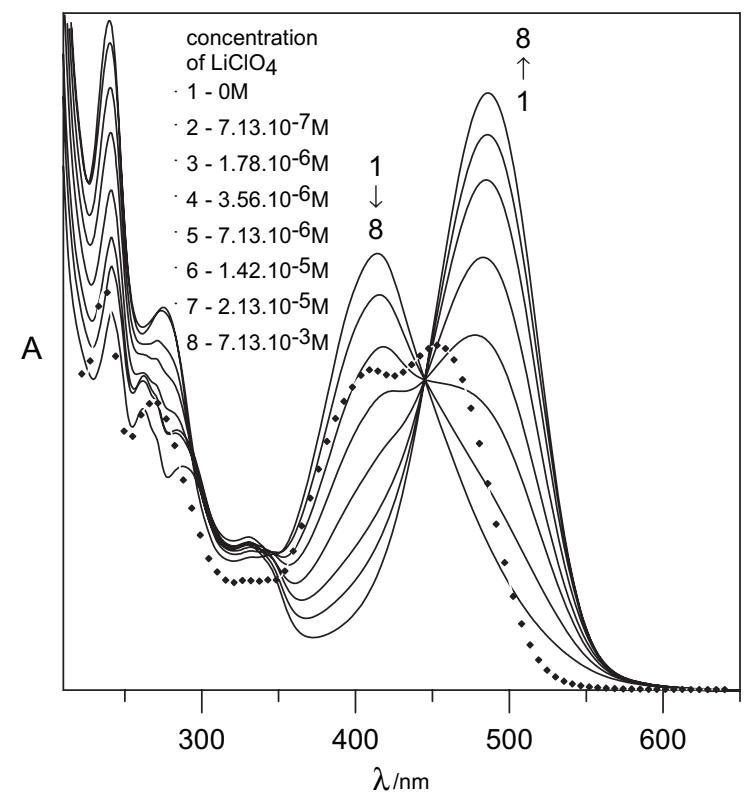

Figure 3. Absorption spectra in dry $\mathrm{CH}_{3} \mathrm{CN} / \mathbf{3}$ with stepwise addition of $\mathrm{LiClO}_{4} ; \mathbf{2}(\bullet)$.

The absorption spectra of $\mathbf{3}$ in dry acetonitrile upon addition of $\mathrm{LiClO}_{4}$ are shown in Figure 3. It is clear that the tautomeric equilibrium is shifted towards the keto tautomer as a result of a complexation, providing substantial red shift $(71 \mathrm{~nm})$ and increased intensity of the new maximum at $486 \mathrm{~nm}$. Consequently, the new ligand exploits the tautomeric proton exchange in the signal conversion.

The complexation abilities of $\mathbf{3}$ towards some alkali and alkaline earth metal ions were studied and the obtained spectra of the final complexes are given in Figure 4, indicating the reached maximal concentrations of the corresponding salts (determined by their solubility in dry acetonitrile). It was observed that upon stepwise addition of the metal salts the spectral behaviour in the case of alkali metal ions differs from that in alkaline earth ones. In the case of $\mathrm{LiClO}_{4}$ and $\mathrm{NaClO}_{4}$ addition 1:1 complex formation was assumed due to the rise of single new band (Fig. 3), corresponding to the shift of the tautomeric equilibrium towards the keto tautomer. ${ }^{40}$ In the

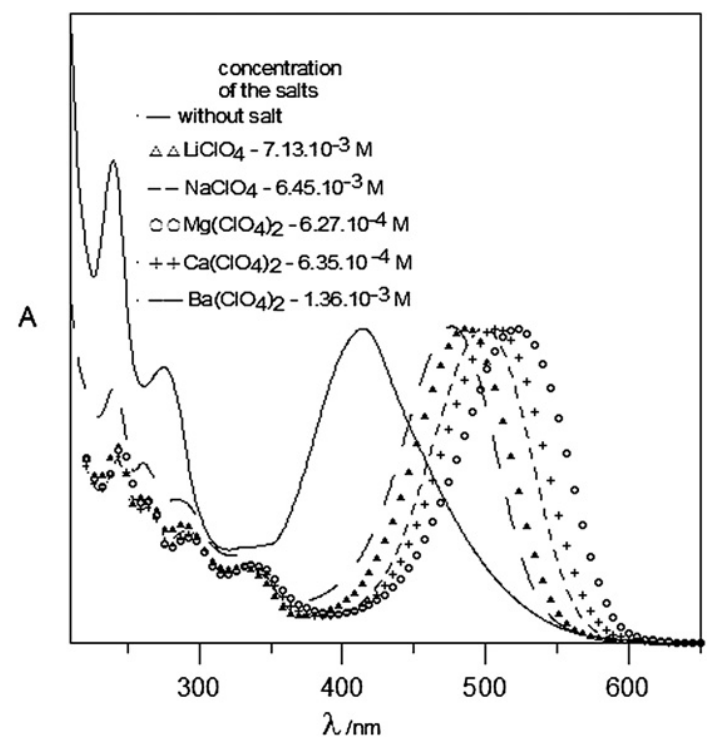

Figure 4. Normalized absorption spectra of $3(-)$ in $\mathrm{CH}_{3} \mathrm{CN}$ and its final complexes with alkali and alkaline earth metal ions. case of $\mathrm{Mg}\left(\mathrm{ClO}_{4}\right)_{2}$ and $\mathrm{Ca}\left(\mathrm{ClO}_{4}\right)_{2}$ an absorption maximum corresponding to the 1:1 complex was observed initially (Fig. 5). Upon further addition of the salt a new red shifted band appeared, corresponding to 2:2 complex. Upon addition of $\mathrm{Ba}\left(\mathrm{ClO}_{4}\right)_{2}$ directly $2: 2$ complex was observed. At these conditions it was impossible to determine the stability constants of the 1:1 complexes of magnesium, calcium and barium complexes.

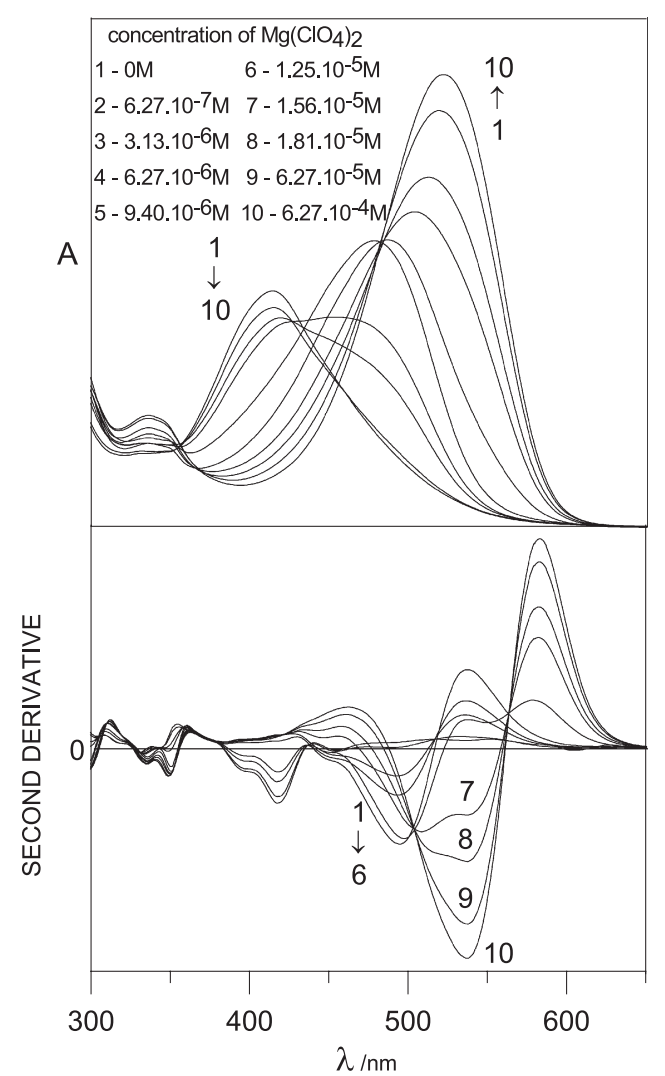

Figure 5. Absorption spectra of 3 in dry $\mathrm{CH}_{3} \mathrm{CN}$ with stepwise addition of $\mathrm{Mg}\left(\mathrm{ClO}_{4}\right)_{2}$ (up) and their second derivatives (down).

It is interesting to mention that in all salts used (except Ba $\left.\left(\mathrm{ClO}_{4}\right)_{2}\right)$ the formation of $1: 1$ complex leads to spectral shift of appr. $70 \mathrm{~nm}$, which corresponds to the appearance of the keto tautomer. This means that the metal ion interacts with the $\mathrm{C}=0$ group and stabilizes 3K form. Further addition of the metal ion causes in the case of alkaline earth metal ions an easy shift of the process to 2:2 complex. In the case of $\mathrm{Na}^{+}$this happens under very high excess of the metal salt and never occurs in the case of $\mathrm{Li}^{+}$addition.

The estimated stability constants and the absorption spectra maxima of the complexes are collected in Table 1. As seen, the

Table 1

Absorption maxima, spectral shifts and stability constants of the complexes of $\mathbf{3}$ in dry $\mathrm{CH}_{3} \mathrm{CN}$

\begin{tabular}{lllcl}
\hline Metal ion & Complex type & $\lambda_{\max }$ complex $[\mathrm{nm}]$ & $\Delta \lambda[\mathrm{nm}]$ & $\log \beta$ \\
\hline $\mathrm{Li}^{+}$ & $1: 1$ & 486 & 71 & $5.28 \pm 0.16$ \\
$\mathrm{Mg}^{2+}$ & $1: 1$ & 492 & 77 & - \\
& $2: 2$ & 522 & 107 & $14.1 \pm 0.3$ \\
$\mathrm{Na}^{+}$ & $1: 1$ & 476 & 61 & $4.21 \pm 0.05$ \\
& $2: 2$ & 518 & 103 & - \\
$\mathrm{Ca}^{2+}$ & $1: 1$ & 491 & 76 & - \\
& $2: 2$ & 509 & 94 & $15.3 \pm 0.4$ \\
$\mathrm{Ba}^{2+}$ & $1: 1$ & - & - & - \\
& $2: 2$ & 500 & 85 & $15.2 \pm 0.04$ \\
\hline
\end{tabular}


complex formation causes substantial red shift, which varies with the metal ion nature and the complex composition. It is worth mentioning that the stability constants show substantial improvement in respect of those of $\mathrm{N}$-phenylaza-15-crown-5 (4, Scheme 3$),{ }^{44}$ where the macrocycle is conjugated to the chromophore system. At the same time, the differences in the stability

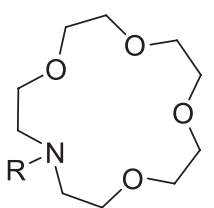

$4 \mathrm{R}=\mathrm{C}_{6} \mathrm{H}_{5}$

$5 \mathrm{R}=\mathrm{CH}_{2} \mathrm{CH}_{2} \mathrm{CH}_{3}$

$6 \mathrm{R}=\mathrm{CH}_{2} \mathrm{CH}_{2} \mathrm{OCH}_{3}$
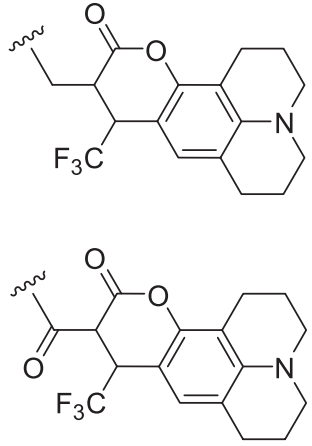

Scheme 3. Compounds with similar aza-15-crown-5 functionality.

constants in $\mathbf{3}$ in respect of the cation are not as profound as in $\mathbf{4}$ (Table 2). For instance, 3 shows strong complexation with $\mathrm{Li}^{+}$and $\mathrm{Mg}^{2+}$, which does not fit well with the size of the aza-15-crown-5 ether cavity. The difference in the complexation of $\mathbf{4}$ with $\mathrm{Ca}^{2+}$ and $\mathrm{Ba}^{2+}$ is one order of magnitude, while the corresponding stability constants are very similar in 3. A possible explanation could be found in the action of the active side-arm (the carbonyl group), which allows the existence of two metal capturing motifs: small (tautomeric carbonyl group, macrocyclic nitrogen and some of the neighbouring macrocyclic oxygens) and large (tautomeric carbonyl group and the whole aza-crown). The small capturing moiety allows complexation with small atoms like magnesium and lithium, behaviour, which is not typical for aza-15-crown-5. This conclusion is supported by the observed negligible complexation with alkali metal ions of the model analogue of $\mathbf{3}$ possessing a piperidine fragment instead of aza-15-crown-5. ${ }^{40}$ The large complexation motif allows strong complexation with large atoms, but reduces the selectivity, because the lack of size fit effect (size of the aza-crown/ size of the metal ion) is compensated by the strong side-arm support. However, as seen from Figure 4 and Table 1, the difference in the spectral maxima of the complexes allows detection of each of the studied cations.

Table 2

Stability constants $(\log \beta)$ of $1: 1$ complexes of 4-8

\begin{tabular}{llllccc}
\hline Metal ion & Solvent & $\mathbf{4}^{44}$ & $\mathbf{5}^{45}$ & $\mathbf{6}^{45}$ & $\mathbf{7}^{46}$ & $\mathbf{8}^{47}$ \\
\hline $\mathrm{Li}^{+}$ & $\mathrm{CH}_{3} \mathrm{CN}$ & & & & $6.2 \pm 0.2$ & $4.05 \pm 0.05$ \\
$\mathrm{Mg}^{2+}$ & $\mathrm{CH}_{3} \mathrm{CN}$ & $2.5 \pm 0.3$ & & & $6.20 \pm 0.05$ & $4.3 \pm 0.1$ \\
$\mathrm{Na}^{+}$ & $\mathrm{CH}_{3} \mathrm{CN}$ & $2.4 \pm 0.1$ & & & $5.10 \pm 0.04$ & \\
& $\mathrm{MeOH}$ & & 3.22 & 4.33 & & \\
$\mathrm{Ca}^{2+}$ & $\mathrm{CH}_{3} \mathrm{CN}$ & $4.84 \pm 0.03$ & & & $6.7 \pm 0.1$ & $3.97 \pm 0.07$ \\
& $\mathrm{MeOH}$ & & 2.86 & 3.78 & & \\
$\mathrm{~K}^{+}$ & $\mathrm{CH}_{3} \mathrm{CN}$ & & & & $4.20 \pm 0.01$ & \\
& $\mathrm{MeOH}$ & & 3.0 & 4.20 & & \\
$\mathrm{Ba}^{2+}$ & $\mathrm{CH}_{3} \mathrm{CN}$ & $3.70 \pm 0.05$ & & & $6.74 \pm 0.08$ & \\
\hline
\end{tabular}

It is interesting to compare the complexation ability of $\mathbf{3}$ with those of 4-8, where the aza-15-crown-5 functionality is used. If we consider 5 as a pure example of an aza-15-crown-5 macrocycle, compound $\mathbf{6}$ is an example with a methoxy passive side-arm, which increases the complexation ability by one order of magnitude. As seen, the values, which we obtained for $\mathbf{3}$ are similar for $\mathrm{Na}^{+}$. Compounds $\mathbf{7}$ and $\mathbf{8}$ possessing a carbonyl side group give substantial values of the stability constants for 1:1 complexes. The reasons, which lead to formation of 2:2 complexes in the case of $\mathbf{3}$ remain unknown, but the
X-ray crystallographic data for $\mathbf{3 K}-\mathbf{N a}$ clearly show that the tautomeric carbonyl group interacts with $\mathrm{Na}^{+}$in a similar way as in $\mathbf{7}$ and $\mathbf{8}$. The possible explanation for the lower strength of the $\mathrm{C}=\mathrm{O}$ group in $\mathbf{3}$ comparing to $\mathbf{7}$ is the structure of the chromophore unit. Compound $\mathbf{7}$ contains a structure with clearly defined electron-donative and electron-withdrawing parts and the electron-withdrawing character of the carbonyl group is reinforced by the cation upon complexation. In the case of $\mathbf{3}$ the donative nature of the tautomeric $-\mathrm{NH}-$ group is reduced by the surrounding substituents, which influences the complexation ability of the $\mathrm{C}=\mathrm{O}$ part. Obviously the simple charge transfer mechanism cannot explain the large red shift in $\mathbf{3 K}-\mathbf{M e}$ - charge transfer in $\mathbf{7}$ and proton transfer in $\mathbf{3}$ lead to difference in the red spectral shift-from $57 \mathrm{~nm}$ in $7^{46}$ to $107 \mathrm{~nm}$ in $\mathbf{3}$ (both for the magnesium complex). This shows clearly how the idea proposed by us could lead to design of new sensing molecules using the tautomeric proton transfer chromophore units as signal converters.

In summary, we report herein on the design and synthesis of an aza-15-crown-5-containing sensing molecule with an active side-arm based on tautomeric proton exchange, which provides enhanced complexation ability and substantial red shift in the absorption spectra under complexation. However, the new ligand needs improvement of the selectivity through structural modifications in the tautomeric sensing block or/and reducing the flexibility of the aza-crown ether.

\section{Experimental}

\subsection{Synthesis}

3.1.1. General. All reagents were purchased from Aldrich, Merck and Fluka and were used without any further purification. Fluka silica gel/TLC-cards 60778 with fluorescent indicator $254 \mathrm{~nm}$ were used for TLC chromatography and $R_{f}$-values determination. The high performance flash chromatography (HPFC) purifications were carried out on a Biotage HorizonTM system (Charlottesville, Virginia, USA) on silica gel. The melting points were determined in capillary tubes on MEL-TEMP 1102D-230 VAC (Dubuque, IA, USA) apparatus without corrections. The NMR spectra were recorded on a Bruker Avance II+ 600 spectrometer (Rheinstetten, Germany) with fid resolution $0.3 \mathrm{~Hz}$, i.e., $5 \times 10^{-4} \mathrm{ppm}$; the chemical shifts were quoted in parts per million in $\delta$-values against tetramethylsilane (TMS) as an internal standard and the coupling constants were calculated in hertz. The NMR spectra at room temperature show slow exchange resulting in: (a) some signals for the crown ether protons appear as broad multiplets or even as broad singlets; (b) the most part of the aromatic $\mathrm{CH}$ and quaternary carbons show broad signals; some are very weak and their detection in a reasonable time-scale is not explicit. The correct assignment of the latter was confirmed by applying 2D techniques. The mass spectra were taken on a DFS High Resolution Magnetic Sector MS, Thermo Scientific.

3.1.2. Synthesis of 3. To a solution of 1 -aza- 15 -crown-5 (3.3 mmol) in benzene $(20 \mathrm{ml})$ paraformaldehyde $(3.3 \mathrm{mmol}), p$-toluenesulfonic acid $(20 \mathrm{mg})$, and then crude $\mathbf{2}^{42}(3 \mathrm{mmol})$ were added and the mixture was refluxed with stirring for $3 \mathrm{~h}$. The products were partitioned between benzene and deionized water. The organic phase was dried over $\mathrm{Na}_{2} \mathrm{SO}_{4}$, and evaporated to dryness. Purification by HPFC on silica gel: mobile phase with a gradient of polarity from cyclohexane/acetone $90: 10$ to cyclohexane/acetone $20: 80 ; 47 \%$ overall yield of 2-((1,4,7,10-tetraoxa-13-azacyclopentadecan-13-yl) methyl)-4-(phenyldiazenyl)naphthalen-1-ol 3; $R_{f} 0.28$ (acetone); very low mp, non-measurable; ${ }^{1} \mathrm{H}$ NMR $\left(\mathrm{CDCl}_{3}\right) 2.894(\mathrm{t}, 4 \mathrm{H}, J$ 5.0, $2 \mathrm{CH}_{2}-\mathrm{N}$ crown), 3.635 (t, $4 \mathrm{H}, \mathrm{J} 4.1,2 \mathrm{CH}_{2}-\mathrm{O}$ crown), 3.707 (t, 4H, J 5.3, $2 \mathrm{~N}-\mathrm{CH}_{2}-\mathrm{CH}_{2}-\mathrm{O}$ crown), $3.743\left(\mathrm{~m}, 8 \mathrm{H}, 4 \mathrm{CH}_{2}-\mathrm{O}\right.$ crown), $4.034(\mathrm{~s}$, $\left.2 \mathrm{H}, \mathrm{Ar}-\mathrm{CH}_{2}-\mathrm{N}\right), 7.428(\mathrm{~m}, 1 \mathrm{H}, \mathrm{CH}-4 \mathrm{Ph}), 7.528(\mathrm{~m}, 3 \mathrm{H}, \mathrm{CH}-8 \mathrm{Ar}$ and $\mathrm{CH}-3$ and $\mathrm{CH}-5 \mathrm{Ph}), 7.622(\mathrm{t}, 1 \mathrm{H}, J$ 7.2, $\mathrm{CH}-7 \mathrm{Ar}$ ), 7.723 (br s, $1 \mathrm{H}$, 
$\mathrm{CH}-3 \mathrm{Ar}$ ), 7.976 (d, 2H, J 6.6, $\mathrm{CH}-2$ and $\mathrm{CH}-6 \mathrm{Ph}$ ), 8.331 (d, 1H, J 8.3, $\mathrm{CH}-9 \mathrm{Ar}), 8.933$ (d, $1 \mathrm{H}, J \mathrm{7.2}, \mathrm{CH}-6 \mathrm{Ar}) ;{ }^{13} \mathrm{C}$ NMR $\left(\mathrm{CDCl}_{3}\right) 54.43$ $\left(2 \mathrm{CH}_{2}-\mathrm{N}\right.$ crown $), 59.57\left(\mathrm{Ar}-\mathrm{CH}_{2}-\mathrm{N}\right), 68.61\left(2 \mathrm{~N}-\mathrm{CH}_{2}-\mathrm{CH}_{2}-\mathrm{O}\right.$ crown), $70.25\left(2 \mathrm{CH}_{2}-\mathrm{O}\right.$ crown $), 70.30\left(2 \mathrm{CH}_{2}-\mathrm{O}\right.$ crown $), 70.66$ $\left(2 \mathrm{CH}_{2}-\mathrm{O}\right.$ crown $), 113.46(\mathrm{CH}-3 \mathrm{Ar}), 115.10\left(C_{\text {quat }}-2\right), 122.43(\mathrm{CH}-9 \mathrm{Ar})$, $122.64(\mathrm{CH}-6 \mathrm{Ar}), 122.87$ ( $\mathrm{CH}-2$ and $\mathrm{CH}-6 \mathrm{Ph}), 125.21$ ( $\left.\mathrm{C}_{\text {quat }}-10 \mathrm{Ar}\right)$, 125.31 ( $\mathrm{CH}-8 \mathrm{Ar}), 127.19$ ( $\mathrm{CH}-7 \mathrm{Ar}), 129.04(\mathrm{CH}-3$ and $\mathrm{CH}-5 \mathrm{Ph})$, $129.94(\mathrm{CH}-4 \mathrm{Ph}), 132.70$ ( $\left.C_{\text {quat }}-5 \mathrm{Ar}\right), 139.88$ ( $\left.C_{\text {quat }}-4 \mathrm{Ar}\right), 153.35$ ( $\left.C_{\text {quat }}-1 \mathrm{Ph}\right), 158.54\left(C_{\text {quat }}-1 \mathrm{Ar}\right)$; COSY cross peaks 2.894/3.707, $3.635 / 3.743,7.428 / 7.528,7.528 / 7.622,7.528 / 7.976,7.528 / 8.331$, 7.622/8.933; HSQC cross peaks $2.894 / 54.43,3.635 / 70.66,3.707 /$ $68.61,3.743 / 70.25,3.743 / 70.30,4.034 / 59.57,7.428 / 129.94,7.528 /$ $125.31,7.528 / 129.04,7.622 / 127.19,7.723 / 113.46,7.976 / 122.87,8.331 /$ 122.43, 8.933/122.64; HMBC cross peaks 2.894/54.43, 2.894/59.57, $2.89 / 68.61,3.635 / 68.61,3.635 / 70.30,3.707 / 54.43,3.707 / 70.25$, 3.743/70.25, 4.034/54.43, 4.034/113.46 (weak), 4.034/115.10, 4.034/ 158.54, 7.428/122.87 (weak), 7.528/122.64, 7.528/125.21, 7.528/ $129.04,7.528 / 153.35,7.528 / 132.70$ (weak), 7.622/122.43, 7.622/ 125.31 (weak), 7.622/132.70, 7.976/122.87, 7.976/129.94,7.976/153.35 (weak), 8.331/127.19, 8.331/132.70, 8.331/158.54, 8.933/125.31; MS $\left(\mathrm{ESI}^{+}\right) \mathrm{m} / z 480\left([\mathrm{M}+1]^{+}\right) ; \mathrm{C}_{27} \mathrm{H}_{33} \mathrm{~N}_{3} \mathrm{O}_{5}+\mathrm{H}$.

3.1.3. Synthesis of $\mathbf{3 K}-\mathbf{N a}$. When satd aq $\mathrm{K}_{2} \mathrm{CO}_{3}$ was used instead of water during the work-up, sodium complex of the keto form of 3 $(\mathbf{3 K}-\mathbf{N a})$ was isolated: $21 \%$ overall yield; orange crystals, mp 230-231 ${ }^{\circ} \mathrm{C}$; ${ }^{1} \mathrm{H}$ NMR (DMSO- $d_{6} / \mathrm{CDCl}_{3} 1: 1$ ) 2.627 (t, 4H, J 4.7, $2 \mathrm{CH}_{2}-\mathrm{N}$ crown $), 3.486\left(\mathrm{~m}, 8 \mathrm{H}, 2 \mathrm{~N}-\mathrm{CH}_{2}-\mathrm{CH}_{2}-\mathrm{O}\right.$ and $2 \mathrm{CH}_{2}-\mathrm{O}$ crown), $3.570\left(\mathrm{~m}, 6 \mathrm{H}, \mathrm{Ar}-\mathrm{CH}_{2}-\mathrm{N}\right.$ and $2 \mathrm{CH}_{2}-\mathrm{O}$ crown), 3.640 (br s, $4 \mathrm{H}, 2 \mathrm{CH}_{2}-\mathrm{O}$ crown), $7.195(\mathrm{~m}, 2 \mathrm{H}, \mathrm{CH}-8 \mathrm{Ar}$ and $\mathrm{CH}-4 \mathrm{Ph}), 7.416(\mathrm{~m}$, $3 \mathrm{H}, \mathrm{CH}-7 \mathrm{Ar}$ and $\mathrm{CH}-3$ and $\mathrm{CH}-5 \mathrm{Ph}), 7.712(\mathrm{~d}, 2 \mathrm{H}, J 7.5, \mathrm{CH}-2$ and $\mathrm{CH}-6 \mathrm{Ph}), 7.991(\mathrm{~s}, 1 \mathrm{H}, \mathrm{CH}-3 \mathrm{Ar}), 8.241(\mathrm{~d}, 1 \mathrm{H}, \mathrm{J} 8.2, \mathrm{CH}-9 \mathrm{Ar}), 8.716(\mathrm{~d}$, $1 \mathrm{H}, J$ 8.3, $\mathrm{CH}-6 \mathrm{Ar}) ;{ }^{13} \mathrm{C}$ NMR (DMSO- $\left.d_{6} / \mathrm{CDCl}_{3} 1: 1\right) 53.91\left(2 \mathrm{CH}_{2}-\mathrm{N}\right.$ crown), $58.57\left(\mathrm{Ar}-\mathrm{CH}_{2}-\mathrm{N}\right), 67.34\left(2 \mathrm{~N}-\mathrm{CH}_{2}-\mathrm{CH}_{2}-\mathrm{O}\right.$ crown), 67.87 $\left(2 \mathrm{CH}_{2}-\mathrm{O}\right.$ crown), $68.40\left(2 \mathrm{CH}_{2}-\mathrm{O}\right.$ crown $), 68.51\left(2 \mathrm{CH}_{2}-\mathrm{O}\right.$ crown), 119.38 ( $\left.C_{\text {quat }}-2 \mathrm{Ar}\right), 120.61(\mathrm{CH}-2$ and $\mathrm{CH}-6 \mathrm{Ph}), 121.33(\mathrm{CH}-6 \mathrm{Ar})$, 121.63 (CH-8Ar), 121.81 ( $\mathrm{CH}-3 \mathrm{Ar}), 124.93$ (CH-9Ar), 125.68 $(\mathrm{CH}-4 \mathrm{Ph}), 127.06(\mathrm{CH}-7 \mathrm{Ar}), 128.30$ ( $\left.\mathrm{C}_{\text {quat }}-10 \mathrm{Ar}\right), 128.83(\mathrm{CH}-3 \mathrm{and}$ $\mathrm{CH}-5 \mathrm{Ph}), 132.20$ ( $\left.C_{\text {quat }}-4 \mathrm{Ar}\right), 135.59\left(C_{\text {quat }}-5 \mathrm{Ar}\right), 154.47\left(C_{\text {quat }}-1 \mathrm{Ph}\right)$, 177.07 ( $\left.C_{\text {quat }}-1 \mathrm{Ar}\right)$; COSY cross peaks $2.627 / 3.486,3.486 / 3.570$, $7.195 / 7.416,7.195 / 8.241,7.416 / 7.712,7.416 / 8.716$; HSQC cross peaks $2.627 / 53.91,3.486 / 67.34,3.486 / 68.51,3.570 / 58.57,3.570 / 68.40$, 3.640/67.87, 7.195/121.63, 7.195/125.68, 7.416/127.06, 7.416/128.83, 7.712/120.61, 7.991/121.81, 8.241/124.93, 8.716/121.33; HMBC cross peaks 2.627/53.91, 2.627/58.57, 2.627/67.34 (weak), 3.486/53.91, $3.486 / 67.34,3.486 / 68.40,3.570 / 53.91$ (weak), 3.570/68.40, 3.570/ 68.51, 3.640/68.40, 3.640/68.51, 7.195/120.61, 7.195/121.33, 7.195/ 128.30, 7.195/128.83 (weak), 7.416/120.61 (weak), 7.416/124.93, 7.416/128.83, 7.416/135.59, 7.416/154.47, 7.712/120.61, 7.712/125.68, 7.712/154.47 (weak), 7.991/58.57, 7.991/132.20 (weak), 7.991/135.59, 7.991/177.07, 8.241/127.06, 8.241/135.59, 8.241/177.07 (weak), 8.716/ 121.63, 8.716/128.30; $\mathrm{MS}\left(\mathrm{ESI}^{+}\right) \mathrm{m} / z \mathrm{z} 02\left(\mathrm{M}^{+}\right) ; \mathrm{C}_{27} \mathrm{H}_{33} \mathrm{~N}_{3} \mathrm{NaO}_{5}$.

\subsection{Quantum-chemical calculations}

$\mathrm{Ab}$ initio $\mathrm{HF} / 6-31 \mathrm{G}^{* *}$ calculations were performed at University of Basel Computer Center by using the Gaussian 03 program suite. ${ }^{48}$ This level of theory presents an acceptable compromise between the computing costs and accordance with the experimental results. ${ }^{49,50}$ The well known weakness of the HF method is the neglect of electron correlation, but it is also quite common that basis set incompleteness introduces errors opposite to that, leading in some cases to fortuitously good HF results with medium basis sets. ${ }^{51}$

The tautomeric structures shown in Figure 2 and their metal complexes were optimized without restrictions and then were characterized as true minima by vibrational frequency calculations.

\subsection{Spectrophotometric titration}

The absorption spectra were measured on Jasco V-570 UV-visNIR spectrophotometer (equipped with Julabo ED thermostat) at constant temperature of $20^{\circ} \mathrm{C}$. Spectral grade solvents were used (Scharlau Multisolvent).

The complexation was studied in dry acetonitrile (dried with $\mathrm{P}_{2} \mathrm{O}_{5}$, distilled upon $\mathrm{CaH}_{2}$ and kept with molecular sieve). ${ }^{52} \mathrm{AR}$ grade $\mathrm{LiClO}_{4}$ (Fluka), $\mathrm{NaClO}_{4} \cdot \mathrm{H}_{2} \mathrm{O}$ (Fluka), $\mathrm{Mg}\left(\mathrm{ClO}_{4}\right)_{2}$ (Fluka), Ca $\left(\mathrm{ClO}_{4}\right)_{2} \cdot 4 \mathrm{H}_{2} \mathrm{O}$ (Aldrich) and $\mathrm{Ba}\left(\mathrm{ClO}_{4}\right)_{2} \cdot$ aq (Fluka) were vacuum dried at $60^{\circ} \mathrm{C}$ from 3 to 5 days depending on the case.

Due to the red shift upon complexation, the estimation of the stability constants was performed at the maximum of the complex using the final complex spectrum (Fig. 4).

\subsection{X-ray crystallographic investigations}

A crystal of 3K-Na was mounted on a loop and all geometric and intensity data were taken from this crystal. Data collection using Mo $\mathrm{K} \alpha$ radiation $(\lambda=0.71073 \AA$ ) was performed at $150 \mathrm{~K}$ on a STOE IPDSII diffractometer equipped with an Oxford Cryosystem open flow cryostat. ${ }^{53}$ Absorption correction was partially integrated in the data reduction procedure. ${ }^{54}$ The structure was solved by SIR 2004 and refined using full-matrix least-squares on $F^{2}$ with the SHELX-97 package. ${ }^{55,56}$ All heavy atoms could be refined anisotropically. Hydrogen atoms were introduced as fixed contributors when a residual electronic density was observed near their expected positions.

Crystal data: (3K-Na) $\mathrm{C}_{29} \mathrm{H}_{38} \mathrm{~N}_{3} \mathrm{NaO}_{6}, M=547.61$ g.mol ${ }^{-1}$, triclinic, $P-1$ (Nr. 2), $a=10.5837(7) ; b=11.4997(9) ; c=13.740(1) \AA$, $\alpha=65.755(5)^{\circ}, \beta=67.068(5)^{\circ}, \gamma=83.560(6)^{\circ} ; V=1402.0(2) \AA^{3}, Z=2$, $\rho_{\text {calcd }}=1.297 \mathrm{Mg} \mathrm{m}^{-3}, \quad F(000)=584, T=150 \mathrm{~K}, \lambda=0.71073 \AA, \mu($ Mo $\mathrm{K} \alpha)=0.120 \mathrm{~mm}^{-1}, 1.76^{\circ}<\theta<26.76^{\circ}, 5914$ reflections of which 5902 unique and 857 observed, 243 parameters refined, GOOF (on $F^{2}$ )= $0.457, \quad R_{1}=\Sigma\left|F_{0}-F_{\mathrm{c}}\right| / \Sigma F_{0}=0.0435, \quad w R_{2}=0.1776$ for $I>2 \sigma(I)$ and $w R_{2}=0.3119$ for all data.

Compound 3K-Na (Fig. 1) crystallizes from a mixture of DMF and ethanol in the triclinic space group $P-1$. The structure consists of two units A connected via two sodium cations. Each sodium cation is heptacoordinated, five coordination sites are filled by one nitrogen and four oxygen atoms from a crown moiety of one ligand, the two other coordination sites are filled by the oxygen atoms the ketone groups of each unit $\mathrm{A}$. The distances Na1- $\mathrm{O}_{\text {crown }}$ are 2.458 (7), 2.607(8), 2.640(8) and 2.499(6) $\AA$, respectively, for O2, O3, 04 and 05. The Na1-N3 bond is 2.589(8) A long, while Na1-O1 and Na1-O1\# are 2.353(7) and 2.301(7) $\AA$ long. The two sodium cations are 3.433(5) $\AA$ apart. The angle formed by $\mathrm{O} 1-\mathrm{Na} 1-\mathrm{O} 1 \#$ is $84.9(3)^{\circ}$ wide, the angles $\mathrm{N} 3-\mathrm{Na} 1-\mathrm{O} 1$ and $\mathrm{N} 3-\mathrm{Na} 1-\mathrm{O} 1 \#$ are 80.3(3) and $117.9(3)^{\circ}$, respectively. $\mathrm{O} 1$ is deprotonated with a distance $\mathrm{C} 14-\mathrm{O} 1$ of $1.26(1) \AA$ and angles of $119.9(6)^{\circ}$ and $141.2(6)^{\circ}$ for C14-O1-Na1 and $\mathrm{C} 14-\mathrm{O} 1-\mathrm{Na} 1 \#$, respectively. The azo-group composed by atoms C1, N1, N2 and C7 is characterized by distances of 1.288(8) $\AA$ for $\mathrm{N} 1-\mathrm{N} 2,1.43(1) \AA$ for $\mathrm{C} 1-\mathrm{N} 1$ and 1.39(1) $\AA$ for $\mathrm{C} 7-\mathrm{N} 2$, the angles $\mathrm{C} 1-\mathrm{N} 1-\mathrm{N} 2$ and $\mathrm{C} 7-\mathrm{N} 2-\mathrm{N} 1$ are $113.1(7)^{\circ}$ and $115.2(8)^{\circ}$ and the torsion angle $\mathrm{C} 1-\mathrm{N} 1-\mathrm{N} 2-\mathrm{C} 7$ is $-174.1(8)^{\circ}$, which is near the perfect conformation. This slightly distorted conformation can be explained by the presence of hydrogen bonding between $\mathrm{N} 1$ and 06, which is the O-atom of the ethanol molecule, and the distance O6 $\cdots \mathrm{N} 1$ is 2.891(9) $\AA$. The $\mathrm{H}$-atom of ethanol is weakly delocalized between $\mathrm{O} 6$ and N1 with a distance of $1.112(7) \AA$ for O6-H6A, 1.790 (6) $\AA$ for $\mathrm{N} 1-\mathrm{H} 6 \mathrm{~A}$ and $169.3(5)^{\circ}$ for the angle $\mathrm{O6}-\mathrm{H} 6 \mathrm{~A}-\mathrm{N} 1$.

\section{Acknowledgements}

This work was supported by the Bulgarian National Science Fund (Projects TK-X-1716 and UNA-17/2005), the Swiss National 
Science Foundation (JRP IB7320-110961/1), and the Alexander von Humboldt Foundation.

\section{Supplementary data}

Supplementary data associated with this article can be found in the online version, at doi:10.1016/j.tet.2010.04.049.

\section{References and notes}

1. Ichimura, K.; Oh, S.-K.; Nakagawa, M. Science 2000, 288, 1624-1626.

2. Chemosensors of Ions and Molecular Recognitions; Desvergne, J. P., Czarnik, A. W Eds.NATO ASI Series; Kluwer Academic: Dordrecht, The Netherlands, 1997.

3. de Silva, A. P.; Gunaratne, H. Q. N.; Gunnlaugsson, T.; Huxley, A. J. M.; McCoy, C. P.; Rademacher, J. T.; Rice, T. E. Chem. Rev. 1997, 97, 1515-1566.

4. Amendola, V.; Fabbrizzi, L.; Licchelli, M.; Mangano, C.; Pallavicini, P.; Parodi, L.; Poggi, A. Coord. Chem. Rev. 1999, 190-192, 649-669.

5. Prodi, L.; Bolletta, F.; Montalti, M.; Zaccheroni, N. Coord. Chem. Rev. 2000, 205 , 59-83.

6. Valeur, B.; Leray, I. Coord. Chem. Rev. 2000, 205, 3-40.

7. Arunkumar, E.; Chithra, P.; Ajayaghosh, A.J. Am. Chem. Soc. 2004, 126, 6590-6598.

8. Hanaoka, K.; Kikuchi, K.; Kojima, H.; Urano, Y.; Nagano, T. J. Am. Chem. Soc. 2004, 126, 12470-12476.

9. Parodi, L.; Montalti, M.; Zaccheroni, N.; Dolci, L. S. In Advanced Concept in Fluorescence Sensing, Part A, Topics in Fluorescent Spectroscopy; Geddes, C. D. Lakowicz, J. R., Eds.; Springer: New York, NY, USA, 2005; Vol. 9, pp 1-58.

10. Kuswandi, B.; n/a, N.; Verboom, W.; Reinhoudt, D. N. Sensors 2006, 6, 978-1017.

11. Palacios, M. A.; Wang, Z.; Montes, V. A.; Zyryanov, G. V.; Anzenbacher, P., Jr. J. Am. Chem. Soc. 2008, 130, 10307-10314.

12. Wen, Z. C.; Ferreira, J. A. B.; Costa, S. M. B. J. Photochem. Photobiol., A: Chem. 2008, 199, 98-104.

13. Bren, V. A. Russ. Chem. Rev. 2001, 70, 1017-1036.

14. de Silva, A. P.; McClean, G. D.; Moody, T. S.; Weir, S. M. In Handbook of Photochemistry and Photobiology; Nalwa, H. S., Ed.; American Scientific: Stevenson Ranch, CA, 2003; Vol. 3, pp 217-270.

15. Montalti, M.; Prodi, L.; Zaccheroni, N. In Handbook of Photochemistry and Photobiology; Nalwa, H. S., Ed.; American Scientific: Stevenson Ranch, CA, 2003; Vol. 3, pp 271-317.

16. Callan, J. F.; de Silva, A. P.; Magri, D. C. Tetrahedron 2005, 61, 8551-8588.

17. Yoshida, K.; Mori, T.; Watanabe, S.; Kawai, H.; Nagamura, T. J. Chem. Soc., Perkin Trans. 2 1999, 393-397.

18. Xia, W.-S.; Schmehl, R. H.; Li, C.-J. J. Am. Chem. Soc. 1999, 121, 5599-5600.

19. Bencini, A.; Bianchi, A.; Lodeiro, C.; Masotti, A.; Parola, A. J.; Pina, F.; de Meloc, J. S.; Valtancoli, B. Chem. Commun. 2000, 1639-1640.

20. Steed, J. W. Coord. Chem. Rev. 2001, 215, 171-221.

21. Chang, J. H.; Jeong, Y.; Shin, Y.-K. Bull. Korean Chem. Soc. 2003, 24, 119-122.

22. Shin, E. J. Bull. Korean Chem. Soc. 2006, 27, 1897-1899.

23. Jeon, Y.-M.; Lim, T.-H.; Kim, J.-G.; Gong, M.-S. Macromol. Res. 2007, 15, 473-477.

24. Dubonosov, A. D.; Minkin, V. I.; Bren, V. A.; Shepelenko, E. N.; Tsukanov, A. V. Starikov, A. G.; Borodkin, G. S. Tetrahedron 2008, 64, 3160-3167.

25. Minkin, V. I.; Dubonosov, A. D.; Bren, V. A.; Tsukanov, A. V.Arkivoc 2008, iv, 90-102.

26. Khan, F. A.; Parasuraman, K.; Sadhu, K. K. Chem. Commun. 2009, 2399-2401.

27. Martínez, R.; Zapata, F.; Caballero, A.; Espinosa, A.; Tárraga, A.; Molina, P. Arkivoc 2010, iii, 124-144.

28. Deneva, V.; Burdzhiev, N.; Stanoeva, E.; Antonov, L. Spectrosc. Lett. 2010, 43, 22-27.

29. Coluccini, C.; Pasini, D.; Righetti, P.; Vander Griend, D. A. Tetrahedron 2009, 65 10436-10440.

30. van Verggel, F. C. J. M.; Verboom, W.; Reinhoudt, D. N. Chem. Rev. 1994, 94, 279-299.

31. Gokel, G. W.; Schall, O. F. In Comprehensive Supramolecular Chemistry; Gokel, G. W., Ed.; Pergamon: New York, NY, 1996; Vol. 1, pp 97-152.
32. de Vries, H.; Wiersma, D.-A. J. Chem. Phys. 1980, 72, 1851-1863.

33. Wehrle, B.; Limbach, H.-H.; Zimmermann, H. Bunzenges. B. Phys. Chem. 1987, 91, 941-950.

34. Lyčka, A. Annu. Rep. NMR Spectrosc. 1993, 26, 247-281.

35. de Silva, A. P.; Fox, D. B.; Moody, T. S.; Weir, S. M. Trends Biotechnol. 2001, 19, 29-34.

36. Wu, K.-C.; Ahmed, M. O.; Chen, C.-Y.; Huang, G.-W.; Hon, Y.-S.; Chou, P.-T. Chem. Commun. 2003, 890-891.

37. Kwon, J. Y.; Jang, Y. J.; Lee, Y. J.; Kim, K. M.; Seo, M. S.; Nam, W.; Yoon, J. J. Am. Chem. Soc. 2005, 127, 10107-10111.

38. Ojida, A.; Takashima, I.; Kohira, T.; Nonaka, H.; Hamachi, I. J. Am. Chem. Soc. 2008, 130, 12095-12101.

39. Nedeltcheva, D.; Antonov, L.; Lyčka, A.; Damyanova, B.; Popov, S. Curr. Org. Chem. 2009, 13, 217-239.

40. Antonov, L.; Deneva, V.; Simeonov, S.; Kurteva, V.; Nedeltcheva, D.; Wirz, J. Angew. Chem., Int. Ed 2009, 48, 7875-7878.

41. The crystallographic data for the sodium complex of the keto form of 3 (3K-Na) were deposited at the Cambridge Crystallographic Data Centre and allocated the deposition number CCDC 747603. Copies of the data can be obtained, free of charge, on application to CCDC, 12 Union Road, Cambridge CB2 1EZ, UK; tel: +44 1223 762910; fax: +44 1223 336033; e-mail: deposit@ccdc. cam.ac.uk; http://www.ccdc.cam.ac.uk/deposit.

42. Zincke, T.; Bindewald, H. Ber. Dtsch. Chem. Ges. 1884, 17, 3026-3033.

43. Joshi, H.; Kamounah, F. S.; van der Zwan, G.; Gooijer, C.; Antonov, L. J. Chem. Soc., Perkin Trans. 2 2001, 2303-2308.

44. Antonov, L.; Vladimirova, M.; Stanoeva, E.; Fabian, W. M. F.; Ballester, L.; Mitewa, M. J. Inclusion Phenom. 2001, 40, 23-28.

45. Inoue, Y.; Liu, Y.; Hakushi, T. In Cation Binding by Macrocycles; Inoue, Y., W. Gokel, G., Eds.; Marcel Dekker: New York, NY, 1990, Chapter 1.

46. Bourson, J.; Pouget, J.; Valeur, B. J. Phys. Chem. 1993, 97, 4552-4557.

47. Habib Jiwan, J.-L.; Branger, C.; Soumillion, J.-P.; Valeur, B. J. Photochem. Photobiol. A: Chem. 1998, 116, 127-133.

48. Frisch, M. J.; Trucks, G. W.; Schlegel, H. B.; Scuseria, G. E.; Robb, M. A.; Cheeseman, J. R.; Montgomery, J. A., Jr.; Vreven, T.; Kudin, K. N.; Burant, J. C.; Millam, J. M.; Iyengar, S. S.; Tomasi, J.; Barone, V.; Mennucci, B.; Cossi, M.; Scalmani, G.; Rega, N.; Petersson, G. A.; Nakatsuji, H.; Hada, M.; Ehara, M.; Toyota, K. Fukuda, R. Hasegawa, J.; Ishida, M. Nakajima, T. Honda, Y; Kitao, O.; Nakai, H.; Klene, M.; Li, X.; Knox, J. E.; Hratchian, H. P.; Cross, J. B.; Adamo, C.; Jaramillo, J.; Gomperts, R.; Stratmann, R. E.; Yazyev, O.; Austin, A. J.; Cammi, R.; Pomelli, C.; Ochterski, J. W.; Ayala, P. Y.; Morokuma, K.; Voth, G. A.; Salvador, P.; Dannenberg, J. J.; Zakrzewski, V. G.; Dapprich, S.; Daniels, A. D.; Strain, M. C.; Farkas, O.; Malick, D. K.; Rabuck, A. D.; Raghavachari, K.; Foresman, J. B.; Ortiz J. V.; Cui, Q.; Baboul, A. G.; Clifford, S.; Cioslowski, J.; Stefanov, B. B.; Liu, G.; Liashenko, A.; Piskorz, P.; Komaromi, I.; Martin, R. L.; Fox, D. J.; Keith, T.; AlLaham, M. A.; Peng, C. Y.; Nanayakkara, A.; Challacombe, M.; Gill, P. M. W. Johnson, B.; Chen, W.; Wong, M. W.; Gonzalez, C.; Pople, J. A. Gaussian 03, Revision B.01; Gaussian: Pittsburgh, PA, 2003.

49. Antonov, L.; Kawauchi, S.; Satoh, M.; Komiyama, J. Dyes Pigments 1998, 38, $157-164$.

50. Antonov, L.; Kawauchi, S.; Satoh, M.; Komiyama, J. Dyes Pigments 1999, 40, $163-170$.

51. Sheikhshoaie, I.; Fabian, W. M. F. Curr. Org. Chem. 2009, 13, 149-171.

52. Techniques in Chemistry, 4th ed.; Riddock, J. A., Bunger, W. B., Sakano, T. K., Eds. Organic Solvents-Physical Properties and Methods of Purification; Wiley: New York, NY, 1986; Vol. 2.

53. Cosier, J.; Glazer, A. M. J. Appl. Crystallogr. 1986, 19, 105-107.

54. Blanc, E.; Schwarzenbach, D.; Flack, H. D. J. Appl. Crystallogr. 1991, 24, 1035-1041.

55. Burla, M. C.; Caliandro, R.; Camalli, M.; Carrozzini, B.; Cascarano, G. L.; de Caro, L.; Giacovazzo, C.; Polidori, G.; Spagna, R. J. Appl. Crystallogr. 2005, 38, 381-388.

56. Sheldrick, G. M. SHELX-97, Program for Crystal Structure Refinement; University of Göttingen: Göttingen, 1997. 